\title{
Scientists, state aggressively pursue Pierce's disease
}

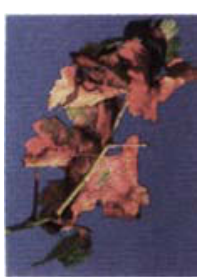

$\mathrm{T}^{\mathrm{r}}$ he threat of Pierce's disease, a fatal bacte1 rial disease of grapes and other crops spread by insects called sharpshooters, is on the rise in California. The disease has been in the state at least since the 1880 s, when it destroyed 40,000 acres of grapes in the Los Angeles basin. While outbreaks have occurred.in vineyards along the coast and in the San Joaquin Valley periodically over the last century, the disease was limited by the fact that native sharpshooters don't fly far from their preferred native habitats.

But all that changed with the accidental introduction of the glassy-winged sharpshooter (GWSS), a half-inch-long leafhopper from the southeastern United States and Mexico that flies much farther and feeds on a greater range of plants than California's native sharpshooters. Named for its transparent wings, GWSS is a voracious eater, consuming up to 10 times its body

\section{Pierce's disease resources}

Pierce's Disease is an authoritative 20-page handbook on the disease, its spread and strategies for containment. Written by UC scientists at the forefront of the battle, the guide is illustrated with 26 photographs and four tables.

Produced by the UC Division of Agriculture and Natural Resources (ANR Publication 21600), Pierce's Disease costs $\$ 6$, plus tax and shipping. It

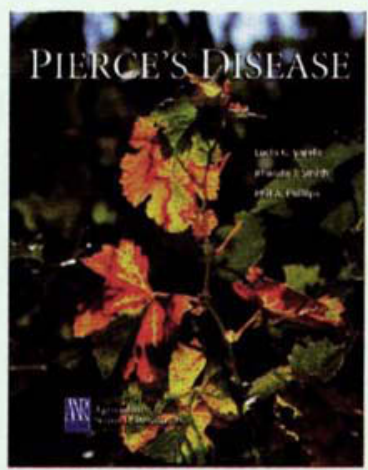
is available from local UC Cooperative Extension offices, ANR Communication Services (6701 San Pablo Avenue, 2nd floor, Oakland, CA 94608-1239), by phone (800-994-8849), fax (510-6435470 ) and online (http: / /anrcatalog.ucdavis.edu). A slide set of photographs from the guide is also available.

$$
\begin{gathered}
\text { Useful Web sites } \\
\text { UC Pierce's disease links: http://danr.ucop.edu/ } \\
\text { California Department of Food and Agriculture: } \\
\text { http://plant.cdfa.ca.gov/gwss/ } \\
\text { Xylella fastidiosa: http://nature.berkeley.edu/xylella/ } \\
\text { California Farm Bureau Federation: } \\
\text { http://www.cfbf.com/issues/gwss/ }
\end{gathered}
$$

weight per hour of plant xylem fluids (the nutrient-poor water transport system of plants).

Pierce's disease is caused by a bacterium, Xylella fastidiosa, which rapidly reproduces in xylem and clogs the vessels that transport water. There is no known cure for the disease: infected grapevines typically develop yellow and brown leaves and die within a few years. Adult sharpshooters that feed on infected plants can pick up the bacteria and harbor them on their mouthparts for the rest of their lives.

GWSS threatens several important agricultural products in California. In addition to the state's $\$ 3.4$ billion wine, table and raisin grape industries, it can spread diseases of alfalfa, almonds, citrus, stone fruits and ornamental plants such as oleander. While the strains of Xylella that cause citrus and stone fruit diseases are not currently established in California, if they were introduced GWSS could spread them rapidly.

\section{Emergency response to spread}

First found in Orange and Ventura counties in 1989, GWSS caused an epidemic of Pierce's disease in Riverside County's Temecula region beginning in 1997. According to state and grower estimates, between 500 and 800 acres of grape vines have been lost to Pierce's disease in Temecula.

Furthermore, GWSS has become established in agricultural, urban and natural areas. According to the California Department of Food and Agriculture (CDFA) and surveys by county agricultural inspectors, six Southern California counties are generally infested: Los Angeles, Orange, Riverside, San Bernardino, San Diego and Ventura. There are also limited infestations in isolated parts of Butte, Contra Costa, Fresno, Kern, Sacramento, Santa Barbara and Tulare counties.

In response to the epidemic, the state legislature passed an emergency bill on May 16, 2000, outlining requirements for county agencies and authorizing CDFA to initiate a control program; at the request of Governor Davis, the U.S. Department of Agriculture (USDA) declared a federal emergency effective June 23,2000 . On July 
25, 2000, CDFA adopted emergency regulations for nursery stock and bulk grapes. An emergency Pierce's Disease Control Program was implemented to arrest the spread of GWSS and, where feasible, eradicate it upon detection in noninfested areas.

Environmental activists and organic growers objected to certain aspects of proposed countybased emerReducing the spread of Pierce's disease adequately may require eliminating more than $95 \%$ to $99 \%$ of the glassywinged sharpshooter population. gency treatment programs, in particular the mandatory spraying of insecticides in residential areas and aerial spraying on agricultural lands. More than 70 groups signed a letter to California Secretary of Agriculture Bill Lyons in December, outlining recommendations for changing the program. CDFA is now in the process of preparing an environmental impact report for the Pierce's Disease Control Program.

\section{$\$ 10$ million for research}

A primary goal of CDFA's Pierce's Disease Control Program is to "contain the spread of GWSS until researchers can find a treatment or cure." Indeed, as of June about $\$ 10$ million had been allocated from a variety of sources (see box), toward dozens of research projects to help stop the spread of Pierce's disease. The UC Pierce's Disease Research and Emergency Response Task Force issued a report on research needs in April 2000; CDFA's Pierce's Disease Advisory Task Force continues to meet regularly.

Controlling Pierce's disease is difficult because "a very small number of glassy-winged sharpshooters are capable of wreaking havoc," says Richard Redak of UC Riverside, who directs DANR's Pierce's Disease Work Group. "It's not an insect problem, it's a disease problem. It makes issues surrounding Medfly management look easy."

Reducing the spread of Pierce's disease adequately may require eliminating more than $95 \%$ to $99 \%$ of the GWSS population, Redak says.
Kern County grape grower Matt Suber checks a yellow sticky trap for glassy-winged sharpshooter. Suber is one of $\mathbf{3 0}$ growers participating in the General Beal Road Pilot Project, a collaborative effort to prevent Plerce's disease on 13,000 acres near Bakersfield.

\section{Funds pour in for Pierce's disease research}

To date, about $\$ 10$ million has been designated for research into controlling GWSS and Pierce's disease.

- As of March 2001, about \$8.2 million had been allocated for more than 50 Pierce's disease research projects, to dozens of scientists affiliated with UC, University of Florida, California State University, Hayward, U.S. Department of Agriculture (USDA), State University of New York and University of Indiana.

- The UC Division of Agriculture and Natural Resources is in the process of distributing an additional $\$ 1.7$ million, through a special grant from the USDA Cooperative State Research, Education and Extension Service (CSREES).
Current major contributors to these efforts are USDA (\$5.15 million) and California Department of Food and Agriculture (\$2.2 million). Additional funding sources include the Almond Board of California, American Vineyard Foundation, California Association of Nurserymen, California Competitive Grant Program for Research in Viticulture and Enology, California Department of Transportation, California Raisin Marketing Board, California Table Grape Commission, Central Coast Pierce's Disease Task Force, Citrus Research Board, City of Temecula, Kern/Tulare GWSS Task Force, Nursery Growers Association of California, Riverside County, Viticulture Consortium and UC Statewide Integrated Pest Management Program.

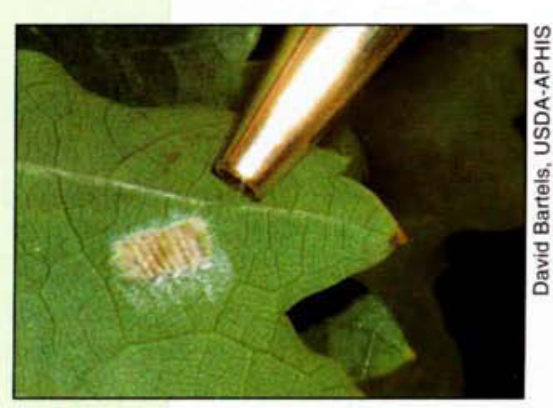

The glassy-winged sharpshooter lays its egg mass (shown) on leaves. Scientists are pursuing a variety of approaches to prevent the nonnative insect from spreading the Xyllela fastidiosa bacterium that causes Pierce's disease in grapevine, other crops and ornamental plants such as oleander. 


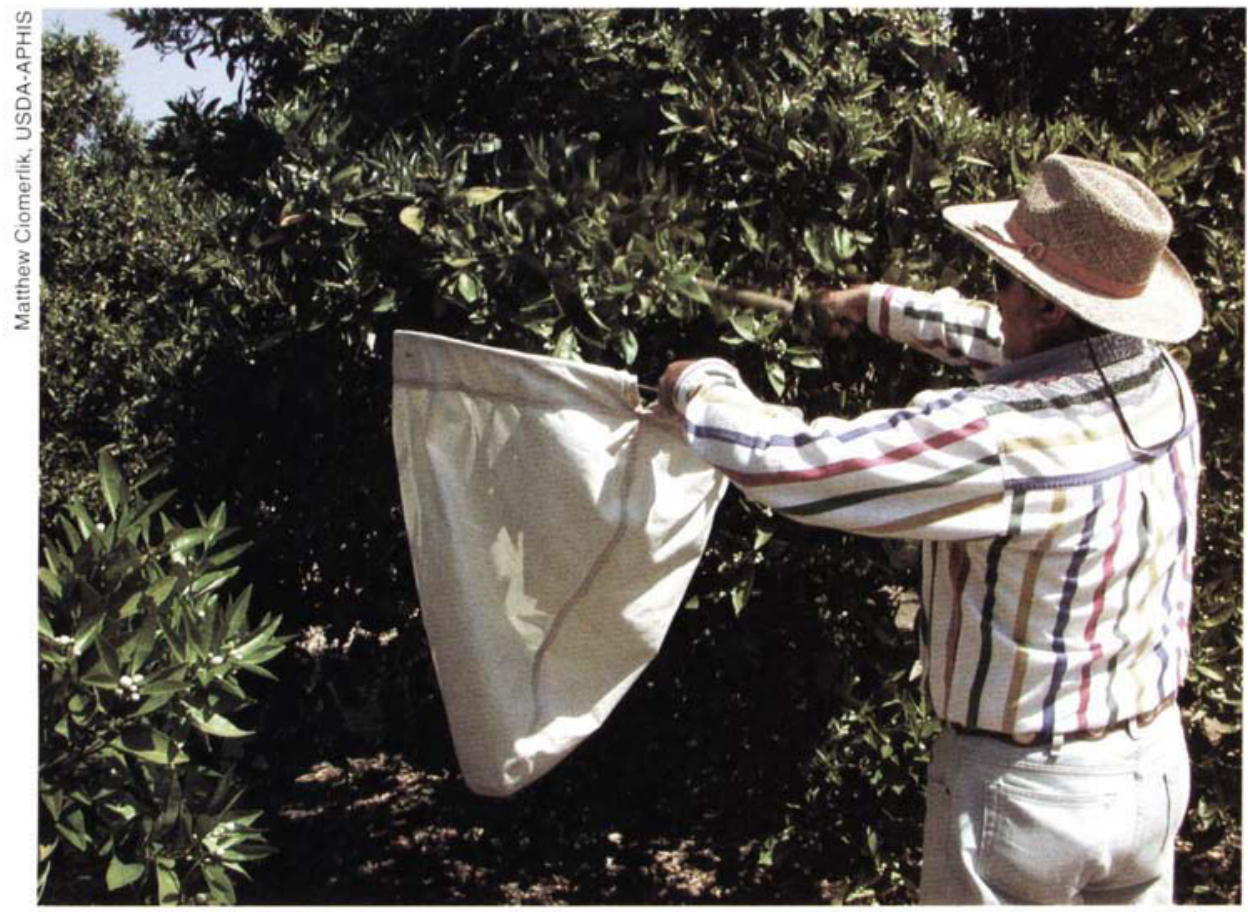

Juan Rodriguez of USDA-APHIS uses the beat-sampling method to detect glassy-winged sharpshooter in citrus. All stages of the insect that fall into the net can be counted.

"No one tactic will be good enough," Matthew Blua of UC Riverside says. "We need to use insecticides, biocontrol, barriers and chemotherapy such as metal ions that reduce Xylella growth."

Dozens of UC researchers are working on both short- and long-term solutions to Pierce's disease, as well as investigating the reproductive behavior of GWSS (see p. 19) and how environmental factors such as proximity to citrus affect the disease's spread (see p. 13).

Pesticides. Insecticides may help to control GWSS, as part of an integrated pest management approach (see p. 22). To reduce the incidence of Pierce's disease in the North Coast, where it is spread primarily by the native blue-green sharpshooter, vineyards should be sprayed with insecticides in late March or early April before the growing season begins, Alexander Purcell of UC Berkeley says. Inoculation experiments show that while vines can become infected with Xylella from April to August, only those infected in April and May develop chronic Pierce's disease. The reason is that as each month passes, the tender growing tips that the native sharpshooters prefer are farther from the base of the plant, which means that the bacteria can't spread far enough down the vine in time to escape being pruned off in the fall.

In contrast, adult GWSS often feed on the woody part of the vine, which means that infections they transmit during the summer can lead to chronic Pierce's disease, Purcell says.

Besides killing sharpshooters outright, insecticides may help keep them from spreading Xylella. To either acquire or transmit the bacterium, sharpshooters must feed on the same plant for several hours. Purcell and Blua are investigating whether sublethal levels of insecticides can disrupt sharpshooter feeding. Blua applied a systemic insecticide, soil-applied imidacloprid (Admire), to experimental grapevines and found that it substantially decreased sharpshooter feeding. In fact, sharpshooter feeding was still disrupted 11 months later: over 2 hours, the insects on treated vines fed only one-fourth as much as those on untreated vines. Because higher levels of imidacloprid inhibit insects' movement, Blua speculates that low levels may keep their feeding muscles from working. The next step is to determine the effects of sublethal insecticides on the transmission of Pierce's disease.

Biocontrol. In the southeastern United States, GWSS populations are partially limited by tiny stingless wasps (including Gonatocerus, Ufens and Zagella species) that lay their eggs in sharpshooter eggs. Once hatched, the wasps eat their way out. Mark Hoddle of UC Riverside and David Morgan of CDFA have released one of these parasitic wasps (Gonatocerus triguttatu) in Riverside County and are also releasing them in Ventura, Kern, Tulare and Fresno counties.

Hoddle and Morgan have found that this introduced wasp can reproduce in GWSS eggs in California during warm weather. They do not yet know whether the wasp can survive winters in California or whether it will help decrease GWSS population.

Chemotherapy. Plant micronutrients such as zinc, manganese and copper are toxic to Xylella grown in laboratory cultures and are registered for use. While it is difficult to get compounds into xylem, Bruce Kirkpatrick of UC Davis has found that when micronutrients are coupled with amino acids and sprayed on leaves, the xylem takes them up efficiently. "This would be such a simple solution with no consumer fallout," Kirkpatrick says.

Genetics. Many scientists believe that genetic manipulation offers the most promising long-term solution to Pierce's disease (see box, p. 11). How-

\section{The glassy-winged sharpshooter is a voracious eater, consuming up to 10 times its body weight per hour of plant xylem fluids.}


ever, it could be problematic, Kirkpatrick says: "Public sentiment tends to be against genetically modified organisms." He is working to protect grapes from Xylella by selectively knocking out the bacterium's genes with a transposon - a mobile piece of DNA that inserts itself into genes. For instance, the transposon might knock out the gene that lets the bacteria stick to sharpshooter mouthparts.

Another approach is to use breeding techniques to develop Xylella- resistant grapes. Andrew Walker of UC Davis is developing hybrids of commercial grapes and Muscadinia rotundifolia, a grape native to the southeastern United States that is resistant to many diseases. While $M$. rotundifolia is Xylella-resistant, it also has some major drawbacks, including that the fruit tastes peculiar and drops off when ripe. Walker is focusing on table and raisin grapes because consumers are pickier about wine grapes and prefer varieties that don't have other species in their background.

By attacking Pierce's disease from all sides, UC researchers may help to control it. "We are hoping that by chiselling away with redundant insect and disease control and management techniques, altogether it may be economically possible to grow grapes in California in the presence of sharpshooters and Pierce's disease," UC Riverside's Redak says.

- Robin Meadows

\section{Genetic research employed to fight Pierce's disease}

Brazilian researchers have sequenced the genome of the Xylella fastidiosa strain responsible for Pierce's disease, the U.S. Department of Agriculture's (USDA) Agricultural Research Service (ARS) announced June 26 . The effort was funded by ARS, American Vineyard Foundation, California Department of Food and Agriculture, and São Paulo State Research Foundation in Brazil.

The work provides an important foundation for determining the functions of individual genes, ARS officials said. Using computers, researchers can compare the

$X$. fastidiosa gene sequences to those from known genomes of other organisms. Because genes with the same sequence usually have the same function, the matching-up process shortens the amount of time it would otherwise take to discover a gene's function.

Scientists anticipate that knowing more about the specific genes that enable X. fastidiosa to replicate inside grapevines, for example, may lead to new, environmentally friendly strategies to protect tomorrow's vineyards from this enemy.
Also, on May 15 the U.S. Patent and Trademark Office issued a patent for the use of a group of genes in grapevines expected to make the plants resistant to Pierce's disease. The patent was issued jointly to the University of Florida and USDA, which collaborated to develop the technology.

"We believe these genes could protect grape plants against a number of diseases, but our target is

Pierce's disease," says Dennis Gray, a UF professor of developmental biology.

Pierce's disease is endemic to the U.S. Southeast, where it prevents the cultivation of Vitis vinifera grape varieties, which include the world's most popular wine and table grapes. Growers in Florida and other Southeastern states are restricted to native Muscadines or Pierce's disease-resistant vinifera hybrids.

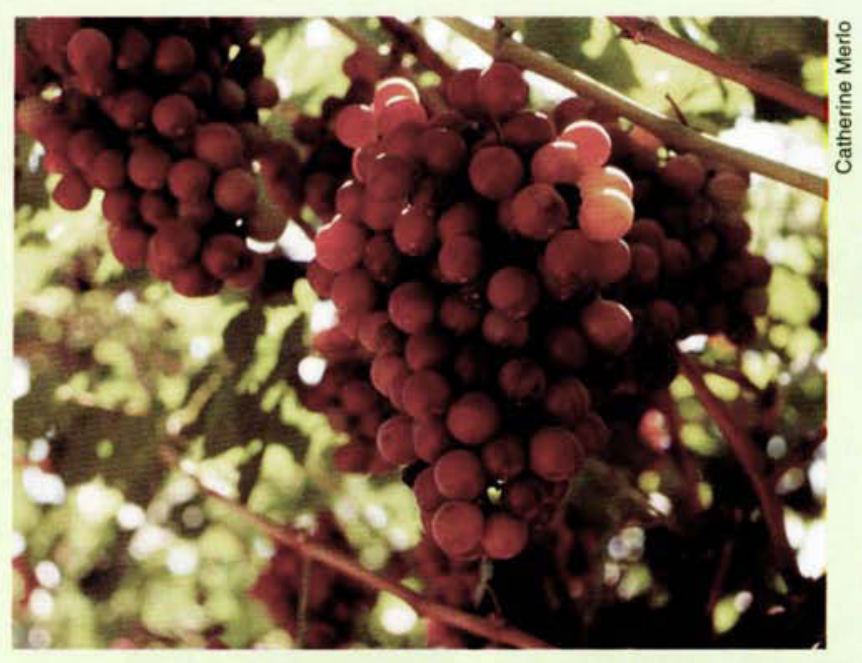

Florida scientists received a patent for genes that may enable the development of grapevines that are resistant to Pierce's disease. Above, Table grapes are grown in Kern County.

The research has received about $\$ 4$ million in funding from UF and Florida's Viticultural Trust Fund. ProfiGen, a Connecticut-based company, has provided financial support and is the exclusive licensee of the patent. ProfiGen anticipates that commercially available grape plants could be available within 5 to 8 years.

-Editors 